\title{
Aberrant DNA methylation in the IFITM1 promoter enhances the metastatic phenotype in an intraperitoneal xenograft model of human ovarian cancer
}

\author{
NAM HEE KIM ${ }^{2 *}$, HYE YOUN SUNG ${ }^{1 *}$, EUN NAM CHOI ${ }^{1}$, DAHYUN LYU ${ }^{1}$, \\ HYUCK JAE CHOI ${ }^{3}$, WOONG JU ${ }^{2}$ and JUNG-HYUCK AHN ${ }^{1}$
}

\begin{abstract}
Departments of ${ }^{1}$ Biochemistry and ${ }^{2}$ Obstetrics and Gynecology, School of Medicine, Ewha Womans University, Yangcheon-ku, Seoul 158-710; ${ }^{3}$ Department of Radiology and Research, Institute of Radiology, University of Ulsan, College of Medicine, Asan Medical Center, Songpa-ku, Seoul 138-736, Republic of Korea
\end{abstract}

Received January 9, 2014; Accepted February 26, 2014

DOI: 10.3892/or.2014.3110

\begin{abstract}
A lack of reliable biomarkers for the early detection and risk of metastatic recurrences makes ovarian cancer the most lethal gynecological cancer. To understand the molecular mechanisms involved in ovarian cancer metastasis in vivo, we analyzed the transcriptional expression pattern in metastatic implants of human ovarian carcinoma xenografts in mice. The expression of 937 genes was significantly different, by at least 2 -fold, in the xenografts compared with that in SK-OV-3 cells. We investigated the mechanisms that regulate the expression of one of the profoundly upregulated genes, interferon-induced transmembrane protein 1 (IFITMI), in the metastatic implants. Specific CpG sites within the IFITM1 promoter were hypomethylated in the metastatic implants relative to those in the wild-type SK-OV-3 cells. Treating wild-type SK-OV-3 cells with the demethylating agent 5-aza-2'-deoxycytidine enhanced IFITM1 expression in a dose-dependent manner, implying transcriptional regulation by promoter methylation. We also found that IFITMI overexpression caused increased migration and invasiveness in SK-OV-3 cells. Our results demonstrate that IFITMI could be a novel metastasis-promoting gene that enhances the metastatic phenotype in ovarian cancer via epigenetic transcriptional regulation. Our findings also
\end{abstract}

Correspondence to: Professor Jung-Hyuck Ahn, Department of Biochemistry, School of Medicine, Ewha Womans University, 911-1 Mok-6-dong, Yangcheon-ku, Seoul 158-710, Republic of Korea E-mail: ahnj@ewha.ac.kr

Professor Woong Ju, Department of Obstetrics and Gynecology, School of Medicine, Ewha Womans University, 911-1 Mok-6-dong, Yangcheon-ku, Seoul 158-710, Republic of Korea

E-mail: goodmorning@ewha.ac.kr

*Contributed equally

Key words: ovarian cancer, metastasis, mouse xenograft, IFITM1, DNA methylation suggest that the status of DNA methylation within the IFITMI promoter region could be a biomarker indicating metastatic progression in ovarian cancer.

\section{Introduction}

Despite progress in cancer therapy, ovarian cancer remains the most lethal gynecological cancer. Since there is no reliable biomarker for early detection, and the early stages of the disease are mostly asymptomatic, the majority of patients with ovarian cancer are diagnosed when the disease is in advanced stages, and the 5-year survival rate is less than $20 \%$ (1). The high mortality rate in ovarian cancer is also linked to a high recurrence rate. Over $70 \%$ of patients with ovarian cancer suffer from recurrence within 2 years of primary standard treatment, which includes total hysterectomy with bilateral salpingo-oophorectomy and subsequent chemotherapy (2). All ovarian cancer recurrences following primary treatment are metastatic recurrences.

Ovarian cancer metastasis has a unique biological behavior that differs from the classical patterns of metastases spreading through the vasculature. Ovarian cancer cells disseminate primarily in the peritoneal cavity and subsequently implant onto mesothelial surfaces (3). The biological process of metastasis is complex at the molecular level, involving adhesion, migration, invasion, growth, proliferation and apoptosis. Understanding the molecular mechanisms of ovarian cancer metastasis will likely lead to novel therapeutic targets and biomarkers that will facilitate better predictions of prognosis.

Interferon-induced transmembrane protein 1 (IFITM1) is a member of the interferon-induced transmembrane protein family and is important for antiproliferative and homotypicadhesion signal transduction in lymphocytes (7-9). IFITM1 also has antiviral functions, inhibiting influenza A replication and enveloped virus infection (10). IFITM1 is upregulated in diverse tumor tissues and cell lines (11-14) and promotes migration and invasiveness in gastric cancer $(15,16)$, glioma (14) and head and neck cancers (17). Furthermore, IFITM1 is reportedly upregulated in response to the anticancer drug paclitaxel in ovarian carcinoma xenografts; however, the role of IFITMI 
and the mechanisms that regulate its expression in ovarian cancer have not yet been elucidated.

Human ovarian carcinoma xenografts are useful tools for analyzing tumorigenicity and for testing the efficacy of newly developed therapies in vivo (3). In particular, intraperitoneal or orthotopic xenografts are useful for modeling the advanced stages of ovarian carcinomas (3). These xenografts produce carcinomatosis in the peritoneal cavity, with large volumes of ascites resembling human ovarian metastatic phenotypes (4-6). We established a mouse xenograft model of human ovarian carcinoma and analyzed transcriptional expression in metastatic implants from the xenografts. The expression pattern of the metastatic implants reflected the pathophysiological condition of ovarian metastatic phenotypes in humans. We selected IFITM1 from among the upregulated genes in the metastatic implants and investigated the mechanism regulating IFITMI expression.

\section{Materials and methods}

Cell culture. The human ovarian cancer cell line SK-OV-3 was purchased from the American Type Culture Collection (ATCC; no. HTB-77) and cultured in McCoy's 5A medium containing $10 \%$ fetal bovine serum (FBS), $100 \mathrm{U} / \mathrm{ml}$ penicillin and $100 \mu \mathrm{g} / \mathrm{ml}$ streptomycin (all from Gibco-BRL) in a $95 \%$ humidified air and $5 \% \mathrm{CO}_{2}$ atmosphere at $37^{\circ} \mathrm{C}$.

Ovarian cancer mouse xenograft model. All procedures for handling and euthanizing the animals used in the present study were performed in strict compliance with the guidelines of the Korean animal protection law and were approved by the Institutional Animal Care and Use Committee (IACUC) of Ewha Womans University School of Medicine. SK-OV-3 cells $\left(2 \times 10^{6}\right)$ suspended in culture media were intraperitoneally injected into 10 female nude mice (BALB/c, 4-6 weeks of age). Four weeks after inoculation, the xenograft mice were sacrificed, and at least four implants adhering to the mesothelial surface of each mouse were harvested.

$R N A$ preparation and quantitative reverse-transcription polymerase chain reaction ( $q R T-P C R)$. Total RNA was extracted from the metastatic implants of the ovarian cancer mouse xenografts and SK-OV-3 cells using the RNeasy Mini kit (Qiagen) according to the manufacturer's protocol. One microgram of total RNA was converted to cDNA using SuperScript II reverse transcriptase and oligo- $(\mathrm{dT})_{12-18}$ primers (both from Invitrogen) according to the manufacturer's instructions. qRT-PCR was performed in a $20-\mu 1$ reaction mixture containing $1 \mu \mathrm{l}$ cDNA, $10 \mu \mathrm{l} \mathrm{SYBR}$ Premix Ex Taq, $0.4 \mu \mathrm{l}$ ROX Reference Dye (50X) (both from Takara Bio), and $200 \mathrm{nM}$ primers for each gene. The primer sequences were: IFITMI (forward), 5'-CGCCAAGTGCCTGAACATCT-3' and IFITMI (reverse), 5'-TACCAGTAACAGGATGAATCCAATG-3'; GAPDH (forward), 5'-AATCCCATCACCATCTTCCA-3' and GAPDH (reverse), 5'-TGGACTCCACGACGTACTCA-3'. The reactions were run on a 7500 Fast Real-Time PCR System (Applied Biosystems) at $95^{\circ} \mathrm{C}$ for $30 \mathrm{sec}$, followed by 40 cycles of $95^{\circ} \mathrm{C}$ for $3 \mathrm{sec}$ and $60^{\circ} \mathrm{C}$ for $30 \mathrm{sec}$, and a single dissociation cycle of $95^{\circ} \mathrm{C}$ for $15 \mathrm{sec}, 60^{\circ} \mathrm{C}$ for $60 \mathrm{sec}$, and $95^{\circ} \mathrm{C}$ for $15 \mathrm{sec}$. All PCR reactions were performed in triplicate, and the specificity of the reaction was detected by melting-curve analysis at the dissociation stage. Comparative quantification of each target gene was performed based on cycle threshold $\left(\mathrm{C}_{\mathrm{t}}\right)$ normalized to GAPDH using the $\triangle \Delta \mathrm{C}_{\mathrm{t}}$ method.

Messenger RNA microarray chip processing and analysis of gene expression data. Total RNA was extracted from the harvested metastatic implants of the ovarian cancer mouse xenografts and SK-OV-3 cells using the RNeasy Mini kit, and $1 \mu \mathrm{g}$ of total RNA was amplified and labeled according to the Affymetrix GeneChip Whole Transcript Sense Target Labeling protocol. The resulting labeled cDNA was hybridized to Affymetrix Human Gene 1.0 ST arrays (Affymetrix). The scanned raw expression values were background corrected, normalized and summarized using the Robust Multi-array Average approach in the Bioconductor 'affy' package (Affymetrix). The resulting $\log _{2}$-transformed data were used for further analyses.

To identify differentially expressed genes (DEGs), we applied moderated t-statistics based on an empirical Bayesian approach (11). Significantly upregulated and downregulated DEGs were defined as genes with at least a 2-fold difference in expression level between the xenograft cells and the wild-type SK-OV-3 cells after correction for multiple testing [Benjamini-Hochberg-false discovery rate (BH-FDR)-adjusted p-value <0.05] (18). Finally, we excluded genes with a low expression level (maximum $\log _{2}$ expression level in a total of 8 samples <7.0) from the list of DEGs. The DAVID bioinformatics resource was used to detect overrepresented GO clusters from the identified DEGs (13).

Bisulfite sequencing PCR (BSP). Genomic DNA was extracted from the harvested metastatic implants of the ovarian cancer mouse xenografts and SK-OV-3 cells using the QIAmp DNA Mini kit (Qiagen) according to the manufacturer's protocol. Bisulfite treatment of genomic DNA was performed using the EpiTect Bisulfite kit (Qiagen) according to the manufacturer's instructions. For bisulfite sequencing of the target promoter region of IFITM1, BSP was carried out using conventional $\mathrm{PCR}$ in a $50-\mu 1$ reaction mixture containing $10 \mathrm{ng}$ bisulfite-modified genomic DNA, $1.5 \mathrm{mM} \mathrm{MgCl}_{2}, 200 \mu \mathrm{M} \mathrm{dNTP}$, 1 U Platinum Taq polymerase (Invitrogen), 1X Platinum Taq buffer, and $200 \mathrm{nM}$ specific BSP forward and reverse primers for each gene. The BSP primers were designed using the MethPrimer software (http://www.urogene.org/methprimer). For IFITM1, the BSP product was $522 \mathrm{bp}$ (position in the human GRCh37/hg19 assembly: ch11 313,635-314,156) and contained $9 \mathrm{CpG}$ sites. The BSP primer sequences were: (forward), 5'-GGATTGTAGTTTGAGGAAAGAGTAAG-3' and (reverse), 5'-AAAAAAAATATTAAATAAAAATTTA AAAAA-3'. The reaction was run at $95^{\circ} \mathrm{C}$ for $5 \mathrm{~min}$, followed by 30 cycles of $95^{\circ} \mathrm{C}$ for $30 \mathrm{sec}, 50-55^{\circ} \mathrm{C}$ for $30 \mathrm{sec}$, and $72^{\circ} \mathrm{C}$ for $30 \mathrm{sec}$ and a final elongation step at $72^{\circ} \mathrm{C}$ for $5 \mathrm{~min}$.

The BSP products were purified using the QIAquick Gel Extraction kit (Qiagen) according to the manufacturer's protocols and ligated into the yT\&A cloning vector (Yeastern Biotech). The ligation products were used to transform competent DH5 $\alpha$ Escherichia coli cells (RBC Bioscience) using standard procedures. Blue/white screening was used to select bacterial clones, and BSP product-positive clones were 
confirmed by colony PCR using the BSP primers to verify the insert size. Plasmid DNA was then extracted from at least 15 insert-positive clones using the QIAprep Spin Miniprep kit (Qiagen) and sequenced using the M13 primer to analyze the methylation status at specific $\mathrm{CpG}$ sites.

Quantitative methylation-specific PCR (qMSP). Quantitative MSP was carried out with bisulfite-modified genomic DNA as the template and specific primer sequences designed to detect the methylated and unmethylated forms of IFITM1. The following methylated/unmethylated-specific primers were used: (forward), 5'-TAGGAAGTTATTAGTTTTGATTTG AGT-3'; (methylated reverse), 5'-TAAAACCTCCTTTCCC CTATCG-3' and (unmethylated reverse), 5'-TAAAACCTCC TTTCCCCTATCA-3'. For qMSP, a 20- $\mu 1$ reaction mixture containing $2 \mu \mathrm{l}$ (10-100 ng/ $\mu \mathrm{l})$ bisulfite-treated DNA, $10 \mu \mathrm{l}$ SYBR Premix Ex Taq (Takara Bio), $0.4 \mu 1$ ROX Reference Dye (50X; Takara Bio), and $200 \mathrm{nM}$ each primer were reacted using a 7500 Fast Real-Time PCR system (Applied Biosystems). The amplification reaction conditions were: $95^{\circ} \mathrm{C}$ for $30 \mathrm{sec}$, followed by 40 cycles of $95^{\circ} \mathrm{C}$ for $3 \mathrm{sec}$, and $62^{\circ} \mathrm{C}$ for $30 \mathrm{sec}$. The PCR product was then reacted at $95^{\circ} \mathrm{C}$ for $15 \mathrm{sec}, 60^{\circ} \mathrm{C}$ for $1 \mathrm{~min}$, and $95^{\circ} \mathrm{C}$ for $15 \mathrm{sec}$ to examine the specificity. Methylation and non-methylation of the specific $\mathrm{CpG}$ sites were calculated as follows ( $\mathrm{Ct}$ represents the threshold cycle): Percent methylation $=100 /\left[1+2^{\left(\Delta \mathrm{Ct}_{\text {meth }}-\Delta \mathrm{Ct}_{\text {nonmeth }}\right)}\right]$.

Treatment with 5-aza-2'-deoxycytidine (5-aza-dC). To demethylate the methylated $\mathrm{CpG}$ sites, SK-OV-3 cells were treated with an increasing concentration $(0,5$ and $10 \mu \mathrm{M})$ of 5-aza-dC (Sigma-Aldrich) for 3 days. The medium was replaced daily.

Transient transfection. To establish a transient expression system, SK-OV-3 cells were transfected with pCMV6-XL5IFITM1 (Origene) or pEGFP-N3 (Clontech) plasmid DNAs using Lipofectamine ${ }^{\mathrm{TM}} 2000$ (Invitrogen). Briefly, the cells were plated at a density of $6 \times 10^{5}$ cells/well in 6-well plates and allowed to grow overnight. Two micrograms of each plasmid DNA and $5 \mu$ l Lipofectamine 2000 were diluted separately in Opti-MEM medium to a total volume of $250 \mu \mathrm{l}$. The diluted plasmid DNAs and Lipofectamine 2000 were mixed and incubated at room temperature for $20 \mathrm{~min}$ to generate the transfection mixtures. The cells were washed with serum-free McCoy's 5A medium, and then the transfection mixtures were added to each well of the 6 -well plates containing complete growth medium and incubated at $37^{\circ} \mathrm{C}$ for $24 \mathrm{~h}$ in a $5 \% \mathrm{CO}_{2}$ incubator.

Transwell migration and in vitro invasion assay. After $24 \mathrm{~h}$ of transfection, the transfected cells were starved by serum deprivation. The cell migration assay was performed in 24-well Transwell plates containing inserts with a polycarbonate membrane with an $8.0-\mu \mathrm{m}$ pore size (Corning). After $24 \mathrm{~h}$ of serum deprivation, the cells were detached from the plates and resuspended in serum-free medium at a density of $2 \times 10^{6}$ cells $/ \mathrm{ml}$. One hundred microliters of the SK-OV-3 cell suspension was added to the upper compartment of the Transwell chamber. For each experiment, both chemotactic migration to medium containing $15 \%$ FBS and random

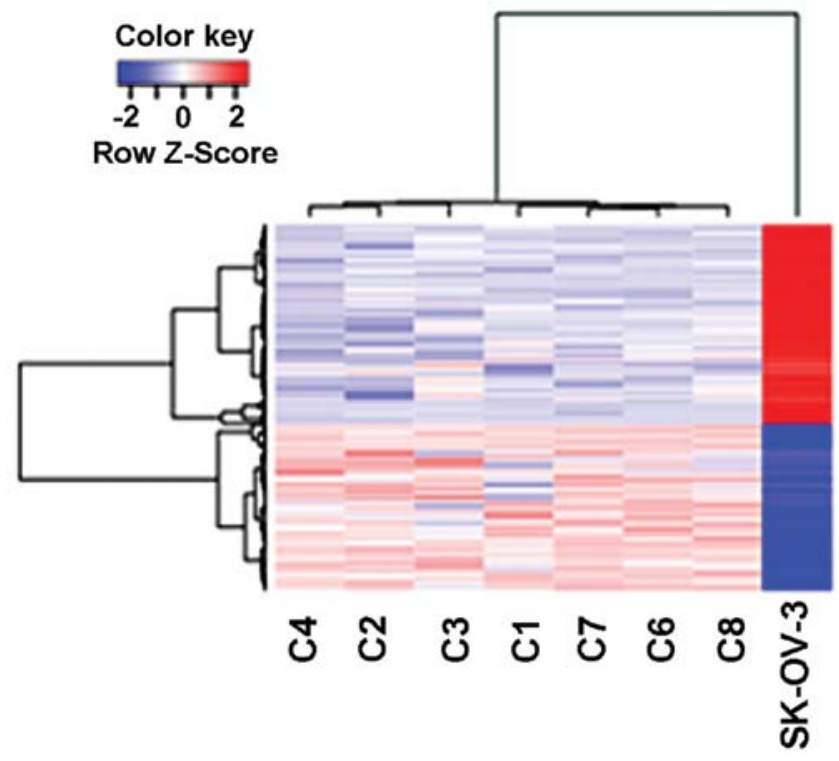

Figure 1. Heatmap and unsupervised hierarchical clustering of the 973 differentially expressed genes. Hierarchical clustering analysis was performed using the Manhattan distance and the Ward algorithm. The metastatic implants from each mouse xenograft are labeled as $\mathrm{C} 1-\mathrm{C} 8(\mathrm{n}=7)$.

migration in serum-free medium were assessed in parallel Transwell plates for $6 \mathrm{~h}$ at $37^{\circ} \mathrm{C}$ in a $5 \% \mathrm{CO}_{2}$ incubator.

The in vitro invasion assay was performed using a BD BioCoat Matrigel Invasion Chamber (Becton-Dickinson). After $24 \mathrm{~h}$ of serum deprivation, SK-OV-3 cells were detached from the plates and resuspended in serum-free medium at a density of $1 \times 10^{6}$ cells $/ \mathrm{ml}$. One hundred microliters of the SK-OV-3 cell suspension was added to the upper compartment of the invasion chamber, and $500 \mu \mathrm{l}$ McCoy's 5A medium containing $10 \%$ FBS was added to the lower compartment of the chamber. The migration through the Matrigel chamber was allowed to proceed at $37^{\circ} \mathrm{C}$ for $24 \mathrm{~h}$ in a $5 \% \mathrm{CO}_{2}$ incubator. After the incubation period, the cells that had not migrated from the upper side of the filter were carefully scraped away with cotton swabs. The cells on the lower side of the filter were fixed for 2 min using Diff-Quick kit solution (Fisher Scientific), stained with $1 \%$ crystal violet for 2 min and washed twice with distilled water at room temperature. The images of the stained cells on the lower side of the membrane were acquired at x 200 magnification in six different fields. For quantitative analysis, the stained cells were subsequently extracted with $10 \%$ acetic acid, and colorimetric measurement was performed at $590 \mathrm{~nm}$.

\section{Results}

Identification of DEGs. A total of 973 genes were found to be differentially expressed in the xenografts relative to the SK-OV-3 cells (Fig. 1). The 444 DEGs that were upregulated were enriched with genes involved in cell adhesion, blood coagulation and wound healing, response to steroid hormone stimulus, blood vessel development and cell mobility (Table I). The 529 DEGs that were downregulated were enriched with genes related to the inflammatory response, regulation of programmed cell death and response to endoplasmic reticulum stress (Table I). 
Table I. Top 10 enriched clusters of gene ontology (GO) in the differentially expressed genes.

\begin{tabular}{|c|c|c|c|c|c|}
\hline $\begin{array}{l}\text { Annotation } \\
\text { cluster }\end{array}$ & $\begin{array}{l}\text { Enrichment } \\
\quad \text { score }\end{array}$ & $\begin{array}{l}\text { Representative two } \\
\text { GO terms in the cluster } \\
\text { (GOTERM_BP_FAT) }\end{array}$ & Count & P-value & $\begin{array}{c}\mathrm{BH} \\
\text { P-value }\end{array}$ \\
\hline \multicolumn{6}{|l|}{ Upregulated } \\
\hline Cluster 1 & 6.8 & $\begin{array}{l}\text { Cell adhesion } \\
\text { Biological adhesion }\end{array}$ & $\begin{array}{l}43 \\
43\end{array}$ & $\begin{array}{l}1.54 \mathrm{E}-08 \\
1.60 \mathrm{E}-08\end{array}$ & $\begin{array}{l}2.86 \mathrm{E}-05 \\
1.48 \mathrm{E}-05\end{array}$ \\
\hline Cluster 2 & 4.1 & $\begin{array}{l}\text { Blood coagulation } \\
\text { Wound healing }\end{array}$ & $\begin{array}{l}12 \\
16\end{array}$ & $\begin{array}{l}2.48 \mathrm{E}-05 \\
4.11 \mathrm{E}-05\end{array}$ & $\begin{array}{l}0.0046 \\
0.0069\end{array}$ \\
\hline Cluster 3 & 4.1 & $\begin{array}{l}\text { Extracellular structure organization } \\
\text { Homophilic cell adhesion }\end{array}$ & $\begin{array}{l}19 \\
16\end{array}$ & $\begin{array}{l}4.59 \mathrm{E}-08 \\
3.85 \mathrm{E}-07\end{array}$ & $\begin{array}{l}2.83 \mathrm{E}-05 \\
1.78 \mathrm{E}-04\end{array}$ \\
\hline Cluster 4 & 3.2 & $\begin{array}{l}\text { Response to drug } \\
\text { Response to steroid hormone stimulus }\end{array}$ & $\begin{array}{l}18 \\
16\end{array}$ & $\begin{array}{l}1.23 \mathrm{E}-05 \\
4.36 \mathrm{E}-05\end{array}$ & $\begin{array}{l}0.0025 \\
0.0062\end{array}$ \\
\hline Cluster 5 & 2.2 & $\begin{array}{l}\text { Nucleosome assembly } \\
\text { Chromatin assembly }\end{array}$ & $\begin{array}{l}10 \\
10\end{array}$ & $\begin{array}{l}1.43 \mathrm{E}-04 \\
1.87 \mathrm{E}-04\end{array}$ & $\begin{array}{l}0.016 \\
0.020\end{array}$ \\
\hline Cluster 6 & 1.8 & $\begin{array}{l}\text { Cell-substrate adhesion } \\
\text { Cell-matrix adhesion }\end{array}$ & $\begin{array}{l}8 \\
7\end{array}$ & $\begin{array}{l}0.0079 \\
0.018\end{array}$ & $\begin{array}{l}0.34 \\
0.49\end{array}$ \\
\hline Cluster 7 & 1.6 & $\begin{array}{l}\text { Ectoderm development } \\
\text { Epidermis development }\end{array}$ & $\begin{array}{l}11 \\
10\end{array}$ & $\begin{array}{l}0.018 \\
0.028\end{array}$ & $\begin{array}{l}0.50 \\
0.60\end{array}$ \\
\hline Cluster 8 & 1.6 & $\begin{array}{l}\text { Blood vessel development } \\
\text { Vasculature development }\end{array}$ & $\begin{array}{l}14 \\
14\end{array}$ & $\begin{array}{l}0.0050 \\
0.0060\end{array}$ & $\begin{array}{l}0.26 \\
0.29\end{array}$ \\
\hline Cluster 9 & 1.5 & $\begin{array}{l}\text { Localization of cell } \\
\text { Cell motility }\end{array}$ & $\begin{array}{l}14 \\
14\end{array}$ & $\begin{array}{l}0.028 \\
0.028\end{array}$ & $\begin{array}{l}0.60 \\
0.60\end{array}$ \\
\hline Cluster 10 & 1.4 & $\begin{array}{l}\text { Collagen metabolic process } \\
\text { Multicellular organismal macromolecule } \\
\text { metabolic process }\end{array}$ & $\begin{array}{l}4 \\
4\end{array}$ & $\begin{array}{l}0.027 \\
0.034756\end{array}$ & $\begin{array}{l}0.59 \\
0.646305\end{array}$ \\
\hline Downregula & & & & & \\
\hline Cluster 1 & 4.9 & $\begin{array}{l}\text { Response to wounding } \\
\text { Inflammatory response }\end{array}$ & $\begin{array}{l}36 \\
25\end{array}$ & $\begin{array}{l}3.36 \mathrm{E}-06 \\
2.08 \mathrm{E}-05\end{array}$ & $\begin{array}{l}0.0041 \\
0.010\end{array}$ \\
\hline Cluster 2 & 4.4 & $\begin{array}{l}\text { Organic acid biosynthetic process } \\
\text { Carboxylic acid biosynthetic process }\end{array}$ & $\begin{array}{l}18 \\
18\end{array}$ & $\begin{array}{l}2.07 \mathrm{E}-06 \\
2.07 \mathrm{E}-06\end{array}$ & $\begin{array}{l}0.0050 \\
0.0050\end{array}$ \\
\hline Cluster 3 & 4.1 & $\begin{array}{l}\text { Serine family amino acid metabolic process } \\
\text { Cellular amino acid biosynthetic process }\end{array}$ & $\begin{array}{r}8 \\
10\end{array}$ & $\begin{array}{l}6.00 \mathrm{E}-06 \\
1.20 \mathrm{E}-05\end{array}$ & $\begin{array}{l}0.0049 \\
0.0073\end{array}$ \\
\hline Cluster 4 & 2.6 & $\begin{array}{l}\text { Regulation of cytokine biosynthetic process } \\
\text { Regulation of cytokine production }\end{array}$ & $\begin{array}{l}10 \\
14\end{array}$ & $\begin{array}{l}2.45 \mathrm{E}-04 \\
0.002082\end{array}$ & $\begin{array}{l}0.045 \\
0.15\end{array}$ \\
\hline Cluster 5 & 2.4 & $\begin{array}{l}\text { Regulation of programmed cell death } \\
\text { Regulation of cell death }\end{array}$ & $\begin{array}{l}43 \\
43\end{array}$ & $\begin{array}{l}1.32 \mathrm{E}-04 \\
1.44 \mathrm{E}-04\end{array}$ & $\begin{array}{l}0.035 \\
0.035\end{array}$ \\
\hline Cluster 6 & 2.4 & $\begin{array}{l}\text { tRNA aminoacylation } \\
\text { Amino acid activation }\end{array}$ & $\begin{array}{l}8 \\
8\end{array}$ & $\begin{array}{l}2.99 \mathrm{E}-04 \\
2.99 \mathrm{E}-04\end{array}$ & $\begin{array}{l}0.051 \\
0.051\end{array}$ \\
\hline Cluster 7 & 2.2 & $\begin{array}{l}\text { Response to endoplasmic reticulum stress } \\
\text { Endoplasmic reticulum unfolded protein response }\end{array}$ & $\begin{array}{l}7 \\
5\end{array}$ & $\begin{array}{l}3.55 \mathrm{E}-04 \\
0.0027\end{array}$ & $\begin{array}{l}0.056 \\
0.17\end{array}$ \\
\hline Cluster 8 & 2.1 & $\begin{array}{l}\text { Serine family amino acid metabolic process } \\
\text { Cysteine metabolic process }\end{array}$ & $\begin{array}{l}8 \\
4\end{array}$ & $\begin{array}{l}6.00 \mathrm{E}-06 \\
4.32 \mathrm{E}-04\end{array}$ & $\begin{array}{l}0.0049 \\
0.064\end{array}$ \\
\hline Cluster 9 & 1.6 & $\begin{array}{l}\text { Vitamin metabolic process } \\
\text { Cellular hormone metabolic process }\end{array}$ & $\begin{array}{l}9 \\
7\end{array}$ & $\begin{array}{l}0.0013 \\
0.0065\end{array}$ & $\begin{array}{l}0.14 \\
0.31\end{array}$ \\
\hline Cluster 10 & 1.6 & $\begin{array}{l}\text { Neuron projection development } \\
\text { Neuron development }\end{array}$ & $\begin{array}{l}17 \\
19\end{array}$ & $\begin{array}{l}0.0028 \\
0.0087\end{array}$ & $\begin{array}{l}0.17 \\
0.35\end{array}$ \\
\hline
\end{tabular}

BH, Benjamini-Hochberg.

Validation of altered IFITM1 expression. From among the 444 upregulated DEGs, we selected IFITM1 as a representative gene to validate the expression microarray results, and we confirmed its expression with qRT-PCR. In agreement with the expression microarray results, IFITM1 mRNA expression was profoundly (2.4- to .4-fold) upregulated in the metastatic implants from the ovarian cancer xenografts $(n=7)$ compared with that in the wild-type SK-OV-3 cells (Fig. 2). 
A

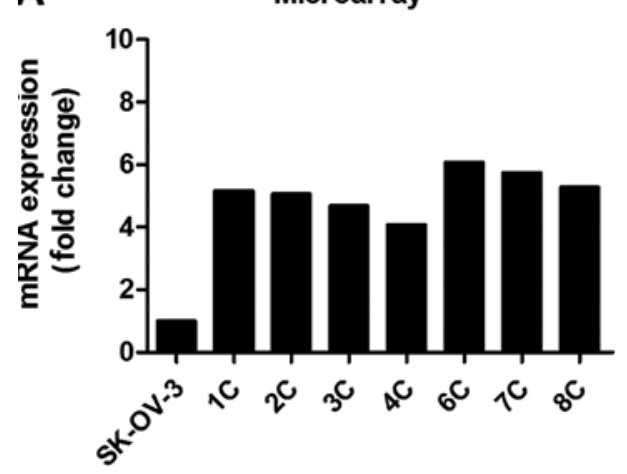

B QRT-PCR

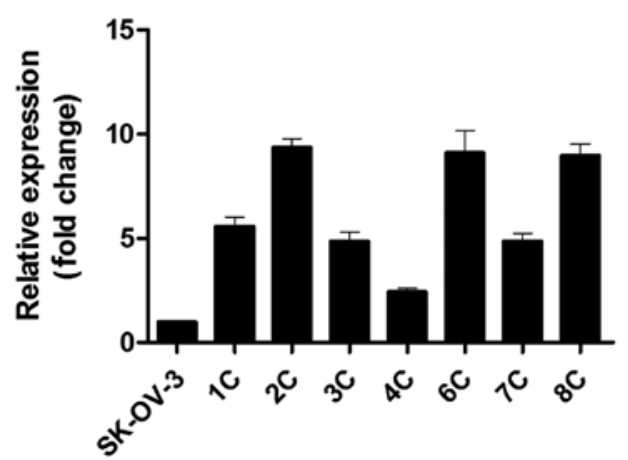

Figure 2.IFITM1 expression is upregulated in metastatic implants from the xenograft mice. IFITM1 mRNA expression was measured by (A) expression microarray and (B) qRT-PCR. The error bars indicate means \pm standard deviation (SD) of triplicate experiments. The metastatic implants from each mouse xenograft are labeled 1C-8C (n=7). IFITM1, interferon-induced transmembrane protein 1; qRT-PCR, quantitative reverse-transcription polymerase chain reaction.

A

IFITM1 (ch11: 313,635 - 314,155)

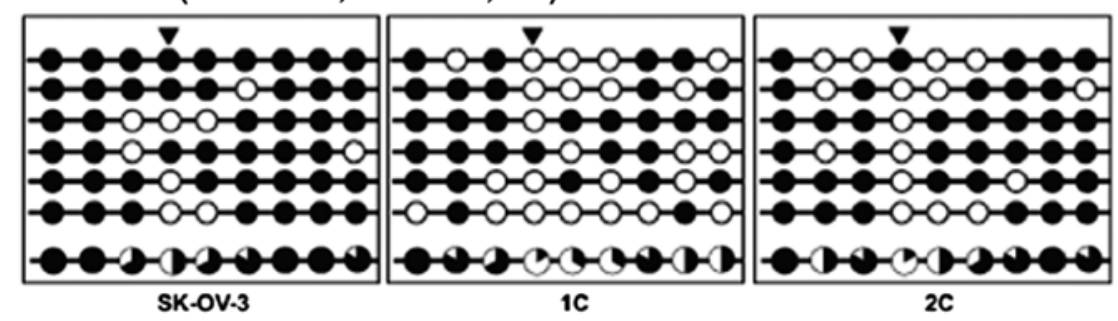

B

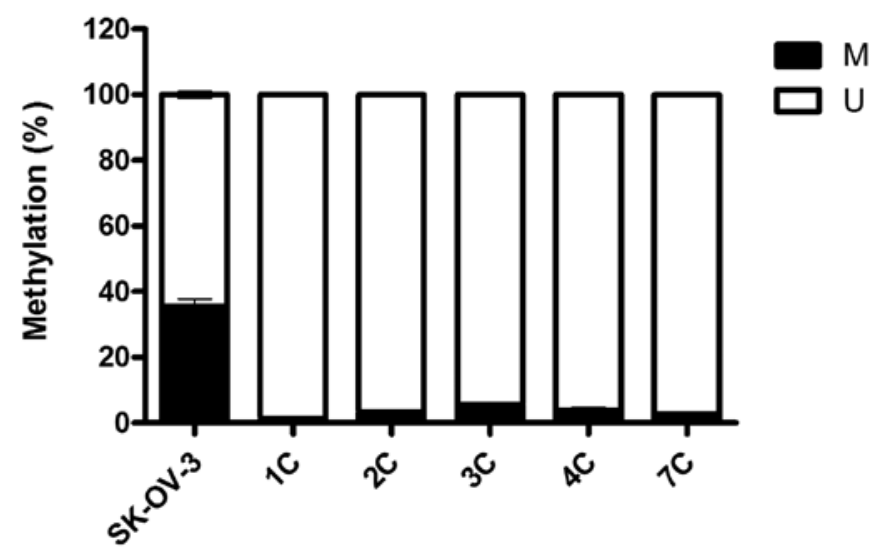

Figure 3. DNA methylation is altered at CpG sites in the IFITM1 promoter in metastatic implants from the mouse xenografts. (A) The DNA methylation status was analyzed using Bisulfite sequencing analysis. The IFITM1 promoter region is located at positions 313,635 - 314,156 in the human GRCh37/hg19 assembly and contains nine $\mathrm{CpG}$ residues within chromosome 11 . The nine $\mathrm{CpGs}$ are located at positions $-310,-272,-236,+54,+84,+96,+108,+116$ and +123 from the transcription start site. Each circle represents $\mathrm{CpG}$ dinucleotides. The methylation status of each $\mathrm{CpG}$ site is illustrated by black (methylated) and white (unmethylated) circles, and the total percentage of methylation at each site is indicated by a pie graph on the bottom line. The black segment of the pie graph indicates the methylated $\mathrm{CpG}$ percentage, whereas the white segment represents the unmethylated $\mathrm{CpG}$ percentage. (B) The DNA methylation status at the +54 CpG site was analyzed using qMSP. Triangles above the circles in A indicate the specific CpG site used for qMSP. M, the percentage of methylated CpGs; U, the percentage of unmethylated CpGs. IFITM1, interferon-induced transmembrane protein 1; qMSP, quantitative methylation-specific PCR.

DNA methylation regulates the expression of IFITM1. The promoter-region $\mathrm{CpG}$ sites in the ovarian metastatic implants were found to be hypomethylated when compared with those in the SK-OV-3 cells, particularly the CpG sites at $-272,+54,+84$ and +96 (Fig. 3A). Further analyses of DNA methylation using MSP revealed significantly reduced methylation at the $+54 \mathrm{CpG}$ site in the ovarian metastatic implants (Fig. 3B). Following treatment with 0,5 and $10 \mu \mathrm{M}$ 5-aza-dC, decreased methylation activity at the $+54 \mathrm{CpG}$ site was confirmed using MSP; and in parallel, the expression of IFITM1 mRNA was significantly increased in a dosedependent manner (Fig. 4). 

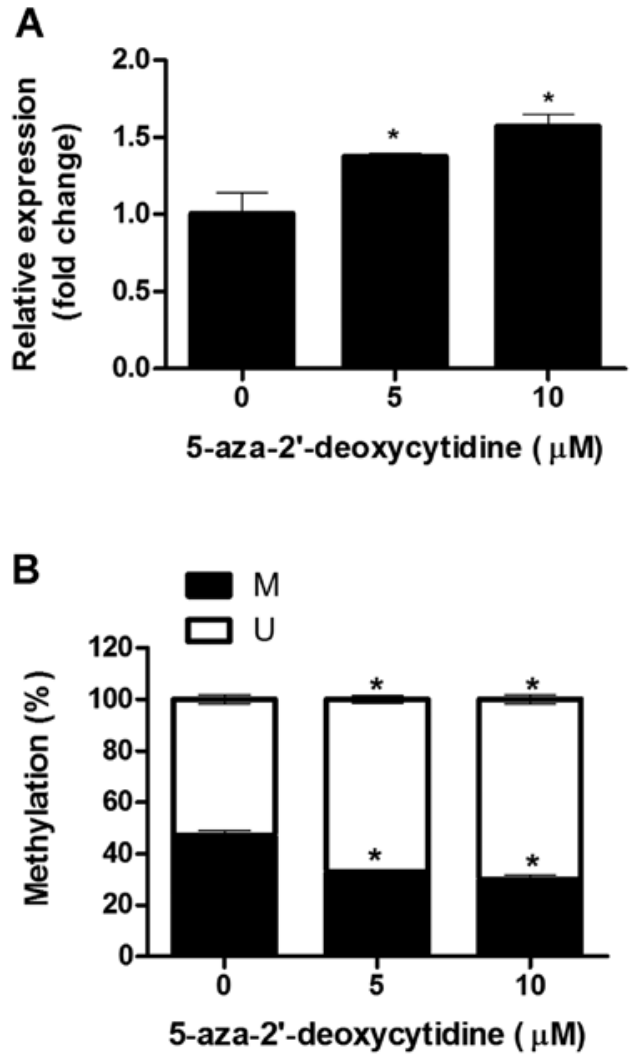

Figure 4. IFITM1 expression changes following demethylation in SK-OV-3 cells. The SK-OV-3 cells were treated for 3 days with 0,5 and $10 \mu \mathrm{M}$ 5 -aza-2'-deoxycytidine, respectively. Following treatment with 5-aza2'-deoxycytidine, (A) IFITM1 mRNA expression was measured by qRT-PCR and (B) the DNA methylation status at the specific $\mathrm{CpG}$ site was analyzed using quantitative MSP. Data are shown as the means $\pm \mathrm{SD}(\mathrm{n}=3)$. Statistical analyses were performed using one-way ANOVA and subsequent Bonferroni tests $\left({ }^{*} \mathrm{p}<0.05\right)$. M, the percentage of methylated $\mathrm{CpG}$; $\mathrm{U}$, the percentage of unmethylated CpG. IFITM1, interferon-induced transmembrane protein 1; qRT-PCR, quantitative reverse-transcription polymerase chain reaction; MSP, methylation-specific PCR.

IFITM1 overexpression induces the migration and invasion of the ovarian cancer cells. To examine the effect of altered IFITM1 expression on metastasis, we performed in vitro migration and invasion assays using Transwell chambers. SK-OV-3 cells were transfected with full-length IFITM1 or enhanced green fluorescence protein (EGFP) cDNA. IFITMI mRNA expression in the transfected cells was confirmed by qRT-PCR (data not shown). The migration capacity of the IFITM1-transfected cells was increased compared with that of the EGFP-transfected cells (Fig. 5). Invasiveness was also markedly increased in the IFITMI-transfected cells compared with that in the EGFP-transfected cells (Fig. 6).

\section{Discussion}

Metastasis is a complex biological process at the molecular level involving adhesion, migration, invasion, growth, proliferation and apoptosis. Metastasizing ovarian cancer cells exhibit unique biological behavior that differs from the classical patterns of metastasis arising at other organ sites (3). Ovarian carcinoma can spread directly to adjacent organs via local invasion, and exfoliated tumor cells can be transported
A
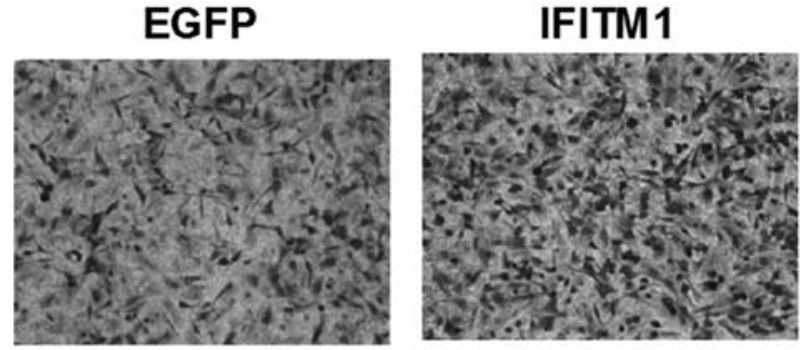

B $\frac{00}{\bar{\delta}}$

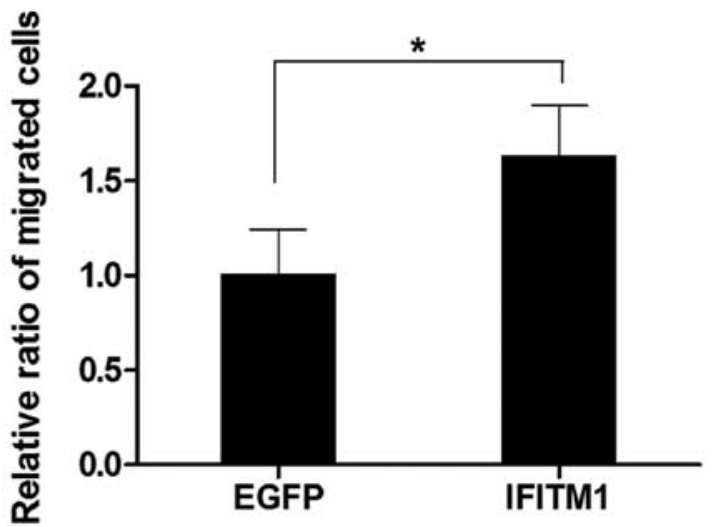

Figure 5. IFITM1 promotes the migration of SK-OV-3 cells. Migration of serum-starved cells towards $15 \%$ serum-containing medium was determined by the Transwell assay. Cells that migrated through an $8-\mu \mathrm{m}$ pore filter were fixed and stained with crystal violet. (A) Representative images of migrated cells transfected with EGFP or IFITM1 are shown. Quantitative analysis of migrated cells was carried out by measuring the absorbance of extracts of cell stains at $595 \mathrm{~nm}$. (B) Data are shown as means \pm SD for triplicate measurements. Statistical analysis was performed using a t-test $\left({ }^{*} \mathrm{p}<0.05\right)$. EGFP, enhanced green fluorescence protein; IFITM1, interferon-induced transmembrane protein 1 .

into the intraperitoneal fluid and subsequently implanted onto mesothelial surfaces. Implantation in the peritoneal cavity is associated with the accumulation of ascites resulting from obstruction of peritoneal lymphatic drainage and the secretion of vascular permeability factors by tumor cells (19).

To better understand the molecular mechanisms involved in ovarian cancer metastasis in vivo, we analyzed transcriptional expression levels in metastatic implants from human ovarian carcinoma xenografts in mice. The expression of 937 genes was significantly altered in the xenografts by at least 2 -fold compared with that in wild-type SK-OV-3 cells (Fig. 1). The upregulated genes were enriched with functions involved in cell adhesion, blood coagulation and wound healing, response to steroid hormone stimulus, blood vessel development and cell mobility (Table I). On the other hand, the downregulated genes were enriched with functions involved in the inflammatory response, the regulation of programmed cell death and response to endoplasmic reticulum stress (Table I).

During the progression of metastasis, ovarian tumor cells exfoliate from their origin and attach to a new location, requiring the remodeling of cell-cell junctions and the alteration of cellular adhesive properties. Our gene ontology (GO) analysis showed that the expression of 43 genes, 
A
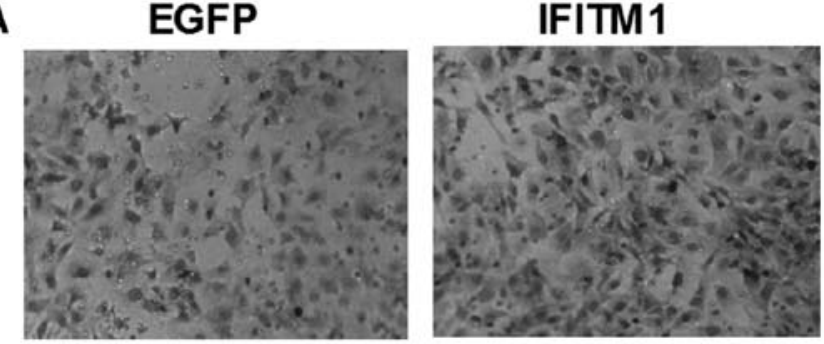

B

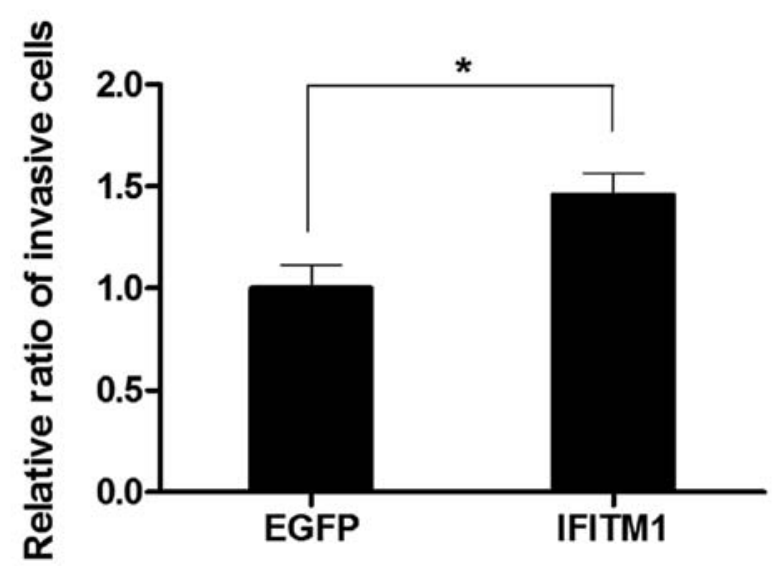

Figure 6. IFITM1 enhances the invasiveness of SK-OV-3 cells. Invasion by serum-starved cells towards $10 \%$ serum-containing medium was determined using a Matrigel-coated invasion chamber. The cells invading through the Matrigel were fixed and stained with crystal violet. (A) Representative images of invading cells transfected with EGFP or IFITM1 are shown. Quantitative analysis of invading cells was carried out by measuring the absorbance of extracts of cell stains at $595 \mathrm{~nm}$. (B) Data are shown as means \pm SD for triplicate measurements. Statistical analysis was performed using a t-test $\left({ }^{*} \mathrm{p}<0.05\right)$. EGFP, enhanced green fluorescence protein; IFITM1, interferoninduced transmembrane protein 1 .

including $P$-cadherin, cadherin 16 , protocadherin 18 and protocadherin $\beta$ cluster, involved in cell adhesion (GO terms: cell, biological, hemophilic cell, calcium-dependent cell-cell and cell-cell adhesion) were significantly upregulated in the metastatic cells (data not shown). In addition to the cadherin and protocadherin families, the expression of certain integrinfamily genes (ITGB4, ITGB6 and ITGA7) was upregulated in the metastatic cells (data not shown). These genes encode adhesion receptors that function in signaling from the extracellular matrix to the cell. Integrin proteins form dimers composed of $\alpha$ and $\beta$ chains; integrin heterodimers can bind to fibronectin, collagen VI, laminin and transforming growth factor 1 (TGF1), promoting cell growth and matrix production by providing physical adhesion between the cytoskeletal structure and the extracellular matrix $(20,21)$.

In human ovarian cancer cell lines, ITGB4 expression is highly elevated in cells expressing aggressive phenotypes. Previously, immunostaining of ITGB4 in 196 human ovarian serous carcinoma samples reveled that high levels of ITGB4 expression were related to tumor aggressiveness (22). Recently, Cheon et al identified 10 collagen-remodeling genes, including COL6A2, that are regulated by TGF- $\beta$ signaling and are associated with metastasis and poor survival among patients with serous ovarian cancer (23). In line with that study, the expression profile of collagen superfamily genes, including COL6A2, was extensively modified in our ovarian metastatic implants (data not shown). The chemokine receptor $C X C R 4$ was also upregulated in the xenografts (data not shown). Scotton et al previously showed that among 14 chemokine receptors, $C X C R 4$ was the only one expressed in ovarian tumor cells (24). The CXCR4 ligand CXCL12 is detectable in ascites in patients with ovarian cancer and is secreted by peritoneal mesothelial cells. The CXCR4-CXCL12 interaction could direct cancer cell migration in the peritoneum, leading to the spread of ovarian cancer (24). We also observed the upregulation of S100 family members (S100A1, S100A2, S100A3 and S100A4) in the metastatic implants (data not shown). S100 family members are overexpressed in many types of cancers and promote metastasis by interacting with many different proteins, including matrix metalloproteinase and by acting as chemoattractants (25). S100A4 has been suggested as a biomarker for the high risk of metastasis and mortality among subgroups of patients with solid tumors, including bladder (26) and breast cancer (27), esophageal squamous cell carcinomas (28), pancreatic cancer (29) and colorectal carcinomas (30).

The expression patterns of certain genes in our xenografts reflect, to some extent, the pathophysiological condition of human metastatic ovarian cancer. IFITM1 is a member of the interferon-induced transmembrane protein family. The upregulation of IFITM1 has been reported in diverse tumor tissues and in cell lines including colorectal (31), head and neck (17) and gastric cancer (16) and glioma (14). IFITMI overexpression is associated with clinicopathological features in colorectal cancer, making it a potential biomarker for clinical diagnosis. The involvement of IFITM1 in cancer progression via the promotion of cell migration and invasion has been demonstrated in gastric and head and neck types of cancers (17). Recently, the epigenetic regulation of IFITMI by aberrant promoter methylation was explored in gastric cancer (16); however, DNA methylation-dependent epigenetic regulation of IFITMI has not been investigated in ovarian cancer.

Our results revealed that IFITM1 expression was profoundly upregulated in metastatic cells, and the methylation of specific $\mathrm{CpG}$ sites within the IFITM1 promoter was highly reduced in the metastatic cells compared with that in the wild-type SK-OV-3 cells (Figs. 2 and 3). Treating wild-type SK-OV-3 cells with the demethylating agent 5 -aza-dC caused dose-dependent enhancement of IFITMI expression, implying transcriptional regulation by promoter methylation. IFITMI overexpression also increased cell migration and invasiveness, suggesting that aberrant upregulation of IFITMI is strongly associated with the acquisition of metastatic phenotypes in ovarian carcinomas.

In conclusion, we used a mouse xenograft model of human ovarian carcinoma to demonstrate that IFITM1 could be a novel metastasis-promoting gene that enhances the metastatic phenotype in ovarian cancer via epigenetic transcriptional regulation. Although further clinical research is warranted, our findings suggest that the status of DNA methylation within the IFITM1 promoter region may be a biomarker indicating metastatic progression in ovarian cancer. 


\section{Acknowledgements}

This study was supported by a grant of the Korean Health Technology R\&D Project, the Ministry of Health and Welfare, Republic of Korea (HI12C0050).

\section{References}

1. Ozols RF: Update on the management of ovarian cancer. Cancer J 8 (Suppl 1): S22-S30, 2002.

2. Tummala MK and McGuire WP: Recurrent ovarian cancer. Clin Clin Adv Hematol Oncol 3: 723-736, 2005.

3. Šle S and Orsulic S: Models of ovarian cancer metastasis: murine models. Drug Discov Today Dis Models 3: 149-154, 2006.

4. Sallinen H, Anttila M, Narvainen J, et al: A highly reproducible xenograft model for human ovarian carcinoma and application of MRI and ultrasound in longitudinal follow-up. Gynecol Oncol 103: 315-320, 2006.

5. Hamilton TC, Young RC, Louie KG, et al: Characterization of a xenograft model of human ovarian carcinoma which produces ascites and intraabdominal carcinomatosis in mice. Cancer Res 44: 5286-5290, 1984.

6. Molpus KL, Koelliker D, Atkins L, et al: Characterization of a xenograft model of human ovarian carcinoma which produces intraperitoneal carcinomatosis and metastases in mice. Int J Cancer 68: 588-595, 1996.

7. Takahashi S, Doss C, Levy S and Levy R: TAPA-1, the target of an antiproliferative antibody, is associated on the cell surface with the Leu-13 antigen. J Immunol 145: 2207-2213, 1990.

8. Bradbury LE, Kansas GS, Levy S, Evans RL and Tedder TF: The CD19/CD21 signal transducing complex of human B lymphocytes includes the target of antiproliferative antibody- 1 and Leu-13 molecules. J Immunol 149: 2841-2850, 1992.

9. Matsumoto AK1, Martin DR, Carter RH, Klickstein LB, Ahearn JM and Fearon DT: Functional dissection of the CD21/CD19/TAPA-1/Leu-13 complex of B lymphocytes. J Exp Med 178: 1407-1417, 1993.

10. Brass AL, Huang IC, Benita Y, et al: The IFITM proteins mediate cellular resistance to influenza A H1N1 virus, West Nile virus, and dengue virus. Cell 139: 1243-1254, 2009.

11. Smyth GK: Linear models and empirical Bayes methods for assessing differential expression in microarray experiments. Stat Appl Genet Mol Biol 3: 3, 2004.

12. Watts GS, Futscher BW, Holtan N, DeGeest K, Domann FE and Rose SL: DNA methylation changes in ovarian cancer are cumulative with disease progression and identify tumor stage. BMC Med Genomics 1: 47, 2008.

13. Huang da W, Sherman BT and Lempicki RA: Systematic and integrative analysis of large gene lists using DAVID bioinformatics resources. Nat Protoc 4: 44-57, 2009.

14. Yu F, Ng SS, Chow BK, et al: Knockdown of interferon-induced transmembrane protein 1 (IFITM1) inhibits proliferation, migration, and invasion of glioma cells. J Neurooncol 103: 187-195, 2011.
15. Yang Y, Lee JH, Kim KY, et al: The interferon-inducible 9-27 gene modulates the susceptibility to natural killer cells and the invasiveness of gastric cancer cells. Cancer Lett 221: 191-200, 2005.

16. Lee J, Goh SH, Song N, et al: Overexpression of IFITM1 has clinicopathologic effects on gastric cancer and is regulated by an epigenetic mechanism. Am J Pathol 181: 43-52, 2012.

17. Hatano H, Kudo Y, Ogawa I, et al: IFN-induced transmembrane protein 1 promotes invasion at early stage of head and neck cancer progression. Clin Cancer Res 14: 6097-6105, 2008.

18. Benjamini $\mathrm{Y}$ and Hochberg Y: Controlling the false discovery rate: a practical and powerful approach to multiple testing. J Roy Stat Soc Ser B (Stat Method) 57: 289-300, 1995.

19. Naora H and Montell DJ: Ovarian cancer metastasis: integrating insights from disparate model organisms. Nat Rev Cancer 5: 355-366, 2005.

20. Howe A, Aplin AE, Alahari SK and Juliano RL: Integrin signaling and cell growth control. Curr Opin Cell Biol 10: 220-231, 1998

21. Aplin A, Howe A, Alahari S and Juliano RL: Signal transduction and signal modulation by cell adhesion receptors: the role of integrins, cadherins, immunoglobulin-cell adhesion molecules, and selectins. Pharmacol Rev 50: 197-263, 1998.

22. Choi YP, Kim BG, Gao MQ, Kang S and Cho NH: Targeting ILK and $\beta 4$ integrin abrogates the invasive potential of ovarian cancer. Biochem Biophys Res Commun 427: 642-648, 2012.

23. Cheon DJ, Tong Y, Sim MS, et al: A collagen-remodeling gene signature regulated by TGF $\beta$ signaling is associated with metastasis and poor survival in serous ovarian cancer. Clin Cancer Res 20: 711-723, 2014.

24. Scotton CJ, Wilson JL, Milliken D, Stamp G and Balkwill FR: Epithelial cancer cell migration: a role for chemokine receptors? Cancer Res 61: 4961-4965, 2001.

25. Salama I1, Malone PS, Mihaimeed F and Jones JL: A review of the S100 proteins in cancer. Eur J Surg Oncol 34: 357-364, 2008.

26. Davies BR, O'Donnell M, Durkan GC, et al: Expression of S100A4 protein is associated with metastasis and reduced survival in human bladder cancer. J Pathol 196: 292-299, 2002.

27. Rudland PS, Platt-Higgins A, Renshaw C, et al: Prognostic significance of the metastasis-inducing protein S100A4 (p9Ka) in human breast cancer. Cancer Res 60: 1595-1603, 2000.

28. Ninomiya I, Ohta T, Fushida S, et al: Increased expression of S100A4 and its prognostic significance in esophageal squamous cell carcinoma. Int J Oncol 18: 715-720, 2001.

29. Ai KX, Lu LY, Huang XY, Chen W and Zhang HZ: Prognostic significance of S100A4 and vascular endothelial growth factor expression in pancreatic cancer. World J Gastroenterol 14: 1931-1935, 2008

30. Gongoll S, Peters G, Mengel M, et al: Prognostic significance of calcium-binding protein S100A4 in colorectal cancer. Gastroenterology 123: 1478-1484, 2002.

31. He JD1, Luo HL, Li J, Feng WT and Chen LB: Influences of the interferon induced transmembrane protein 1 on the proliferation, invasion, and metastasis of the colorectal cancer SW480 cell lines. Chin Med J 125: 517-522, 2012. 